\title{
Carbon and phosphate incorporation rates of microbial assemblages in contrasting environments in the Southeast Pacific
}

\author{
Solange Duhamel ${ }^{1,2, *}$, Thierry Moutin ${ }^{1}$ \\ ${ }^{1}$ Aix-Marseille Université, Laboratoire d'Océanographie Physique et Biogéochimique, LOPB-UMR 6535 CNRS, \\ OSU/Centre d'Océanologie de Marseille, 13288 Marseille, Cedex 09, France
}

${ }^{2}$ Present address: C-MORE and Department of Oceanography, University of Hawaii, Honolulu, Hawaii 96822, USA

\begin{abstract}
Size-fractionated chlorophyll a (chl a) was determined along with carbon (C) and phosphate $(\mathrm{P})$ incorporation rates over a west-east transect in the Southeast Pacific (between $146.36^{\circ} \mathrm{W}$ and $72.49^{\circ} \mathrm{W}$ ). A clear longitudinal gradient was observed for both chl $a$ and $\mathrm{C}$ and $\mathrm{P}$ incorporation rates from the productive areas, near the Marquesas Islands and the Chilean upwelling, to the hyperoligotrophic area associated with the central part of the Southeast Pacific Gyre (SPG). The 0.2-0.6 $\mu \mathrm{m}$ fraction represented 15 to $43 \%(29 \pm 7 \%$ mean $\pm S D, n=24)$ of the $\mathrm{P}$ incorporation rate along the transect, suggesting that heterotrophic bacteria were important factors in the $\mathrm{P}$ cycle as dissolved inorganic $\mathrm{P}$ consumers. Small-sized cells $(<2 \mu \mathrm{m})$ formed the bulk of chl a biomass $(69 \pm 4 \%)$ and accounted for $49 \pm 7 \%$ of total primary production in the SPG. In contrast, large phytoplankton $(>2 \mu \mathrm{m})$ accounted for a significantly larger fraction of the total primary production, despite having lower chl a biomass and $\mathrm{P}$ incorporation rates. Consequently, larger cells presented higher photosynthetic efficiency values than the smaller phytoplankton. The C:P incorporation rate ratios exhibited increasing deviation from the canonical stoichiometric ratios of 106 and 50 (for phytoplankton and heterotrophic bacteria, respectively) towards the centre of the SPG. We propose hypotheses to explain these deviations.
\end{abstract}

KEY WORDS: Phosphate $\cdot$ Carbon $\cdot$ Production $\cdot$ Size fractionation $\cdot$ Chlorophyll $a \cdot$ Hyperoligotrophy Resale or republication not permitted without written consent of the publisher

\section{INTRODUCTION}

The size distribution of microbial assemblages is one of the key factors controlling the function of pelagic food webs (Legendre \& Rassoulzadegan 1996). There is strong evidence that process rates are sizedependent and that food web interactions, at the microbial level, strongly influence carbon (C) production and nutrient regeneration in the pelagic zone. However, despite this, studies of the size distribution of microbial assemblages in biomass and production in tropical and oligotrophic gyres are scarce (Marañón et al. 2001). Many studies of both size-fractionated chlorophyll a $(\mathrm{chl}$ a) and primary production data have been conducted in coastal and/or temperate environ- ments (see review in Legendre \& Rassoulzadegan 1996, Cermeño et al. 2006). In the open-ocean, these factors have been described for Atlantic waters (Marañón et al. 2001, Fernandez et al. 2003, Teira et al. 2005), but no data are available for the South Pacific Ocean.

While heterotrophic bacteria and phytoplankton have contrary roles in the $\mathrm{C}$ cycle as producers and degraders of organic $\mathrm{C}$, they both consume phosphate (P) in the form of dissolved inorganic P (DIP). It is therefore essential to gain a better understanding of microbial C:P stoichiometry because these relationships play a major role in coupled elemental cycles (Falkowski \& Davis 2004). Because the C, N and P cycles are strongly mediated and driven by the biota, 


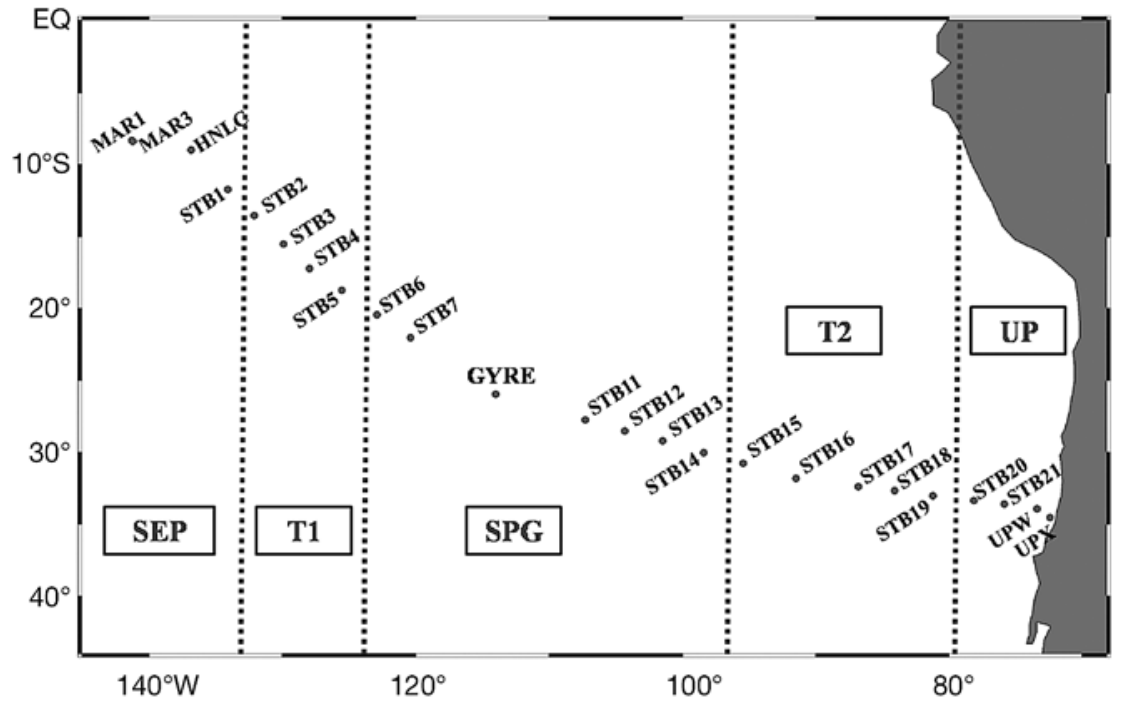

Fig. 1. The BIOSOPE cruise transect in the Southeast Pacific Ocean (OctoberDecember 2004) between Marquesas Islands (MAR) and the Chilean upwelling (UPW-UPX). The 5 areas of the BIOSOPE transect are: the sub equatorial productive area (SEP), Transition Area 1 (T1), the central South Pacific Gyre (SPG), Transition Area 2 (T2) and the upwelling productive area (UP) authors interested in biogeochemical cycles have had the tendency to adopt the Redfield scheme too indiscriminately. Yet, the elemental composition of individual species of phytoplankton grown under $\mathrm{N}$ or $\mathrm{P}$ limitation can diverge from the Redfield ratio (Redfield 1934). Redfield emphasised that the C:P ratio of inorganic nutrients in the ocean was an average and that small-scale variability around the mean was to be expected (Falkowski \& Davis 2004). As the C and P cycles are linked through the stoichiometric composition of microorganism biomass, a parallel determination of the $\mathrm{C}$ and $\mathrm{P}$ budgets in different size fractions should provide a good description of the relative activity of microorganisms (Thingstad et al. 1996).

The oligotrophic waters of the subtropical gyres are estimated to cover more than $60 \%$ of the total ocean surface and to contribute to more than $30 \%$ of the global marine $\mathrm{C}$ fixation (Longhurst et al. 1995). The BIogeochemistry and Optics SOuth Pacific Experiment (BIOSOPE) offered an exceptional opportunity to conduct a basin-scale study of biogeochemical and optical properties of this largely unexplored area (Claustre \& Maritorena 2003), paying particular attention to the hyperoligotrophic area associated with the Southeast Pacific Gyre (SPG) where the clearest waters were encountered (Morel et al. 2007). During this cruise, we assessed the plankton dynamics in terms of $\mathrm{C}$ and $\mathrm{P}$. The recently optimized method of dual ${ }^{33} \mathrm{P}$ and ${ }^{14} \mathrm{C}$ labelling (Duhamel et al. 2006) coupled with size fractionation and the use of bacterial production data, measured from the same CTD bottles, enabled the relative importance of $\mathrm{C}$ and $\mathrm{P}$ incorporation rates in 3 size fractions $(0.2-0.6 ; 0.6-2$ and $>2 \mu \mathrm{m})$ to be determined along a west-east transect through the Southeast Pacific Ocean. We discuss the size distribution of the microbial assemblages in $\mathrm{C}$ and $\mathrm{P}$ incorporation rates and the deviations that were observed from the C:P Redfield ratio, with particular emphasis on the SPG area.

\section{MATERIALS AND METHODS}

Station locations, sample collection and hydrological characteristics. This work was conducted during the BIOSOPE cruise in the Southeast Pacific Ocean (between $146.36^{\circ} \mathrm{W}$ and $72.49^{\circ} \mathrm{W}$; Fig. 1) from October to December 2004. The BIOSOPE transect (Fig. 1) will be described in 5 parts: (1) the Sub Equatorial productive area (SEP) between the Marquesas Islands (MAR; $\left.141.2^{\circ} \mathrm{W}\right)$ and Station STB1 $\left(134.1^{\circ} \mathrm{W}\right) ;(2)$ Transition Area 1 (T1) between STB2 $\left(132.1^{\circ} \mathrm{W}\right)$ and STB5 $\left(127.9^{\circ} \mathrm{W}\right) ;(3)$ the central part of the hyperoligotrophic SPG between STB6 $\left(122.4^{\circ} \mathrm{W}\right)$ and STB14 $\left(98.4^{\circ} \mathrm{W}\right)$; (4) Transition Area 2 (T2) between STB15 (95.4 $\left.{ }^{\circ} \mathrm{W}\right)$ and STB $19\left(81.2^{\circ} \mathrm{W}\right)$; and (5) the Chilean upwelling productive area (UP) between STB20 $\left(78.1^{\circ} \mathrm{W}\right)$ and UPX $\left(72.4^{\circ} \mathrm{W}\right)$. High vertical resolution $(24 \mathrm{~Hz}$ allchannel scan rate), environmental data were collected using a conductivity-temperature-depth-oxygen profiler (CTDO, Seabird 911 Plus), between 0 and $500 \mathrm{~m}$, measuring external temperature, conductivity, salinity, oxygen, fluorescence and depth. Seawater samples for $\mathrm{C}$ and $\mathrm{P}$ incorporation rates, bacterial production, chl a and nutrients were collected from 6 depths corresponding to 6 levels of photosynthetically active radiation $\left(\mathrm{PAR}_{i}\right.$ 50, 25, 15, 7, 3 and $1 \%$ ). These depths were determined using a PAR sensor attached to the rosette. Samples were collected in 121 Niskin bottles attached to a rosette CTD system at 09:00 h (local time). Subsamples were collected directly, without pre-filtration, into clean and sample-rinsed polycarbonate bottles. In 
the oligotrophic area, nitrate concentrations were $<3 \mathrm{nmol} \mathrm{l}^{-1}$ (Raimbault et al. 2008) while DIP concentrations were $>120 \mathrm{nmol} \mathrm{l}^{-1}$ (Moutin et al. 2008). Primary and bacterial productions were shown to be N-limited (Van Wambeke et al. 2007, Bonnet et al. 2008).

Analytical methods. Size-fractionated chl a concentrations were determined by serial filtration of 1 to 1.21 samples onto 2, 0.6 and $0.2 \mu \mathrm{m}$ polycarbonate filters. Immediately after filtration, the filters were put into tubes containing $5 \mathrm{ml}$ of methanol for pigment extraction $\left(30 \mathrm{~min}, 4^{\circ} \mathrm{C}\right)$. The fluorescence was measured using a Turner design 10-AU-005-CE fluorimeter equipped with a chlorophyll a Kit (F4T45.B2 lamp). Total chl $a$ is the sum of chl a concentrations in the 3 fractions. This value was compared to the total chl a determined by high-performance liquid chromatography (HPLC) according to Ras et al. (2008).

Size-fractionated $\mathrm{C}$ and $\mathrm{P}$ incorporation was determined using the ${ }^{33} \mathrm{P} /{ }^{14} \mathrm{C}$ dual labelling method (Duhamel et al. 2006). Duplicate $300 \mathrm{ml}$ samples, from each of the predetermined depths, were treated simultaneously with 2 control samples which were inoculated with $300 \mu \mathrm{l}$ of $\mathrm{HgCl}_{2}$. Samples were inoculated with $1080 \mathrm{kBq}$ carrier-free ${ }^{33} \mathrm{P}\left(<40 \mathrm{pmol} \mathrm{l}^{-1}\right.$ final concentration; orthophosphate in dilute hydrochloric acid; Amersham BF 1003), and $3.7 \mathrm{MBq}{ }^{14} \mathrm{C}$ (bicarbonate aqueous solution; Amersham CFA3). Samples were then incubated under the sunlight, for 4 to $5 \mathrm{~h}$ in on-deck incubators equipped with light filters (nickel screens) to reproduce the appropriate light levels from the sampling depths $(50,25,15,7,3$ and $1 \%$ of transmitted light). $\mathrm{KH}_{2} \mathrm{PO}_{4}$ was used to prevent labelled DIP assimilation and samples were kept in the dark to prevent DIC incorporation. $50 \mathrm{ml}$ sub-samples were then filtered onto $0.2,0.6$ and $2 \mu \mathrm{m}, 25 \mathrm{~mm}$ polycarbonate membranes, that had been placed onto GF/Fs soaked with saturated $\mathrm{KH}_{2} \mathrm{PO}_{4}$, using a low-pressure suction $\quad<0.2$ bars). Un-incorporated ${ }^{33} \mathrm{P}$ and ${ }^{14} \mathrm{C}$ were eliminated by increasing the pressure to 0.6 bars at the end of the filtration step and adding $150 \mu \mathrm{l}$ of $\mathrm{HCl}\left(0.5 \mathrm{~mol} \mathrm{l}^{-1}\right)$, respectively. After 12 h, $6 \mathrm{ml}$ of scintillation liquid (Ultimagold MV scintillation liquid, Packard) was added to each vial before the first counting. Counts per minute (cpm) were carried out on a Packard Tri-Carb ${ }^{\circledR}$ 2100TR scintillation counter. To separate ${ }^{33} \mathrm{P}$ activity from ${ }^{14} \mathrm{C}$ activity, we applied the method using the different half-lives of the 2 isotopes (mean \pm SD: $5700 \pm$ $30 \mathrm{yr}$ for ${ }^{14} \mathrm{C}$ and $25.383 \pm 0.040 \mathrm{~d}$ for ${ }^{33} \mathrm{P}$; Duhamel et al. 2006). The second counts were made following $1 \mathrm{yr}$ of preservation in the dark, at room temperature. Measurements of the $\mathrm{C}$ and $\mathrm{P}$ incorporation rates in each size fraction $(0.2-0.6,0.6-2$ and $>2 \mu \mathrm{m})$ were obtained using difference calculations.

Calculations. Heterotrophic bacteria were separated from phytoplankton by filtering through $0.6 \mu \mathrm{m}$ filters.
Since this method is not free from bias, the percentages of bacterial cells passing through a $0.6 \mu \mathrm{m}$ filter were systematically determined. The picoplankton cell abundances (heterotrophic prokaryotes [herein referred to as bacteria], Prochlorococcus, Synechococcus and picophytoeukaryotes) were determined by flow cytometry (FACSCalibur, Becton Dickinson), at each sampled station and depths, in the total and $<0.6 \mu \mathrm{m}$ samples. Picophytoplankton abundances were determined in situ on fresh samples while bacterioplankton samples were fixed with a final concentration of either $1 \%$ paraformaldehyde or $0.1 \%$ glutaraldehyde and frozen in liquid nitrogen. Samples were then processed according to Grob et al. (2007). On average, $91 \pm 10 \%$ of the heterotrophic bacteria passed through the $0.6 \mu \mathrm{m}$ filter $(\mathrm{n}=90$; all sampled stations and depths included). This value was in the same range as those obtained in other studies $(\sim 80 \%$; Obernosterer et al. 2003). Flow cytometry data showed that Prochlorococcus (when detectable), Synechococcus and Picophytoeucaryotes cells had an average size of $0.68 \pm$ $0.08 \mu \mathrm{m} ; 0.86 \pm 0.1 \mu \mathrm{m}$ and $1.74 \pm 0.13 \mu \mathrm{m}$, respectively over the entire transect (results from Grob et al. 2007). The average cell size of Synechococcus at the upwelling stations was $1.16 \pm 0.02 \mu \mathrm{m}$. Thus the choice of a $0.6 \mu \mathrm{m}$ filter to separate heterotrophic bacteria from phytoplankton cells seems to be appropriate.

The daily primary production (phytoplankton C production) was calculated using the method of Moutin et al. (1999). Daily P incorporation rates and daily bacterial production (heterotrophic bacteria $\mathrm{C}$ production) were calculated by multiplying the hourly rate by 24 . For more details see Duhamel et al. (2007).

Hourly integrated $\mathrm{C}$ and $\mathrm{P}$ incorporation rates

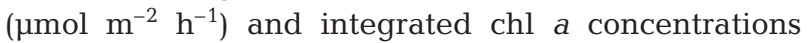
(Ichl $a_{;} \mathrm{mg} \mathrm{m}^{-2}$ ) were calculated between surface and $1 \%$ of transmitted light. Because measurements of $\mathrm{C}$ and $\mathrm{P}$ incorporation rates were made in simulated light conditions, incubation depth values have been corrected using the measured transmitted light levels from each sample depth.

The molar C:P ratios correspond to the ratio between the euphotic-layer-integrated daily $\mathrm{C}$ production estimates (i.e. primary production for phytoplankton and bacterial production for heterotrophic bacteria) by euphotic-layer-integrated daily $\mathrm{P}$ incorporation rates $\left(\mu \mathrm{mol} \mathrm{m} \mathrm{m}^{-2} \mathrm{~d}^{-1}: \mu \mathrm{mol} \mathrm{m} \mathrm{m}^{-2} \mathrm{~d}^{-1}\right.$ ). Since heterotrophic bacteria and phytoplankton cells acquire $\mathrm{C}$ from different sources, the C:P ratios have been calculated differently for the fractions corresponding to these different functional groups. Assuming that the heterotrophic bacteria were smaller than $0.6 \mu \mathrm{m}$, the C:P ratio for the $0.2-0.6 \mu \mathrm{m}$ size fraction corresponds to the ratio between integrated daily bacterial production (estimated from leucine method at the same stations and depths as DIC 
and DIP incorporation rates; data from Van Wambeke et al. 2008) and integrated daily $P$ incorporation rate measured in this size fraction. For the size fractions $>2 \mu \mathrm{m}$ and $0.6-2 \mu \mathrm{m}$, where it was assumed that there is predominately phytoplankton cells, the C:P ratio correspond to the ratio between integrated daily primary production and integrated daily $\mathrm{P}$ incorporation rates measured in the corresponding size fractions.

We used Ocean Data View (3.0.1) (Reiner Schlitzer) and Sigmaplot (9.01) (Systat Software) for the figures and Sigmastat (3.1) (Systat Software) for the statistical analysis.

\section{RESULTS}

\section{Size-fractionated chl a}

We cross-checked that the sum of the chl a concentrations for the 3 size fractions was equal to the total chl a concentration measured. This was achieved by comparing the summed size-fractionated chl a concentrations determined using fluorimetry to the total chl a concentration measured using HPLC (see Ras et al. 2008). The samples were taken from the same depths, though not necessarily the same CTD bottle, for the 5 areas of the transect (Fig. 2). We found significant correlations between these data whatever the area $(p<0.001, n=138)$. The slopes were not significantly different from 1 ( $p<$ 0.001).

The longitudinal distribution of total chl a showed wide variations ranging from 0.02 to $2.08 \mu \mathrm{g} \mathrm{l}^{-1}$ in the euphotic area of the gyre and of the Chilean up- welling, respectively (Fig. 3). The vertical distribution exhibited a deep chl a maximum (DCM) (Fig. 3A), mainly attributed to the 0.6-2 $\mu \mathrm{m}$ size fraction (Fig. 3C), increasing from the edge towards the centre of the gyre and reaching depths of 150 to $200 \mathrm{~m}$. In the oligotrophic domain, chl a concentrations in the 0.6$2 \mu \mathrm{m}$ size fraction were significantly higher in the $\operatorname{DCM}\left(0.14 \pm 0.03 \mu \mathrm{g} \mathrm{l}^{-1}\right)$ than in the upper euphotic zone $\left(0.04 \pm 0.03 \mu \mathrm{g} \mathrm{l}^{-1}, \mathrm{p}<0.001\right)$. The chl a concentration profile for the $>2 \mu \mathrm{m}$ size fraction (Fig. 3B) was fairly uniform, although a slight increase was also observed in the DCM $\left(0.05 \pm 0.02 \mu \mathrm{g} \mathrm{l}^{-1}\right.$ and $0.02 \pm$ $0.01 \mathrm{gg}^{-1}$ for DCM and the upper euphotic zone, respectively, $\mathrm{p}<0.001)$. The chl a concentrations in the 0.2-0.6 $\mu \mathrm{m}$ fraction were very low, ranging between 0 and $0.05 \mu \mathrm{g}^{-1}$ (most of the values were under the detection limit of the method $\left(0.01 \mathrm{Mg} \mathrm{l}^{-1}\right.$; average value $=0.009 \pm 0.007 \mu \mathrm{g} \mathrm{l^{-1 }}$ ), with minimum values observed in the SPG. This confirms that most of the $<0.6 \mu \mathrm{m}$ fraction did not contain any chl a (i.e. the cells were heterotrophic).

The minimum Ichl a value (Fig. 4) was measured in the SPG (STB7: $10.5 \mathrm{mg} \mathrm{m}^{-2}$ ) while the maximum value was measured in the upwelling area (UPW: $92 \mathrm{mg} \mathrm{m}^{-2}$ ). Average Ichl $a$ values were $32 \pm 3 ; 21 \pm 5 ; 20 \pm 6 ; 29 \pm 4$ and $60 \pm 30 \mathrm{mg} \mathrm{m}^{-2}$, in the SEP, T1, SPG, T2, and UP areas, respectively. There were significant variations in the proportion of chl $a$ in the 2 phytoplankton size fractions ( $p<0.001)$. In the $0.2-0.6 \mu \mathrm{m}$ fraction, the amount of chl a was very low throughout the transect $(8 \pm 4 \%)$ whereas in the $0.6-2 \mu \mathrm{m}$ fraction it was greater than $40 \%$ over the entire BIOSOPE transect, with the exception of Station UPW (8\%), with maximum values in the

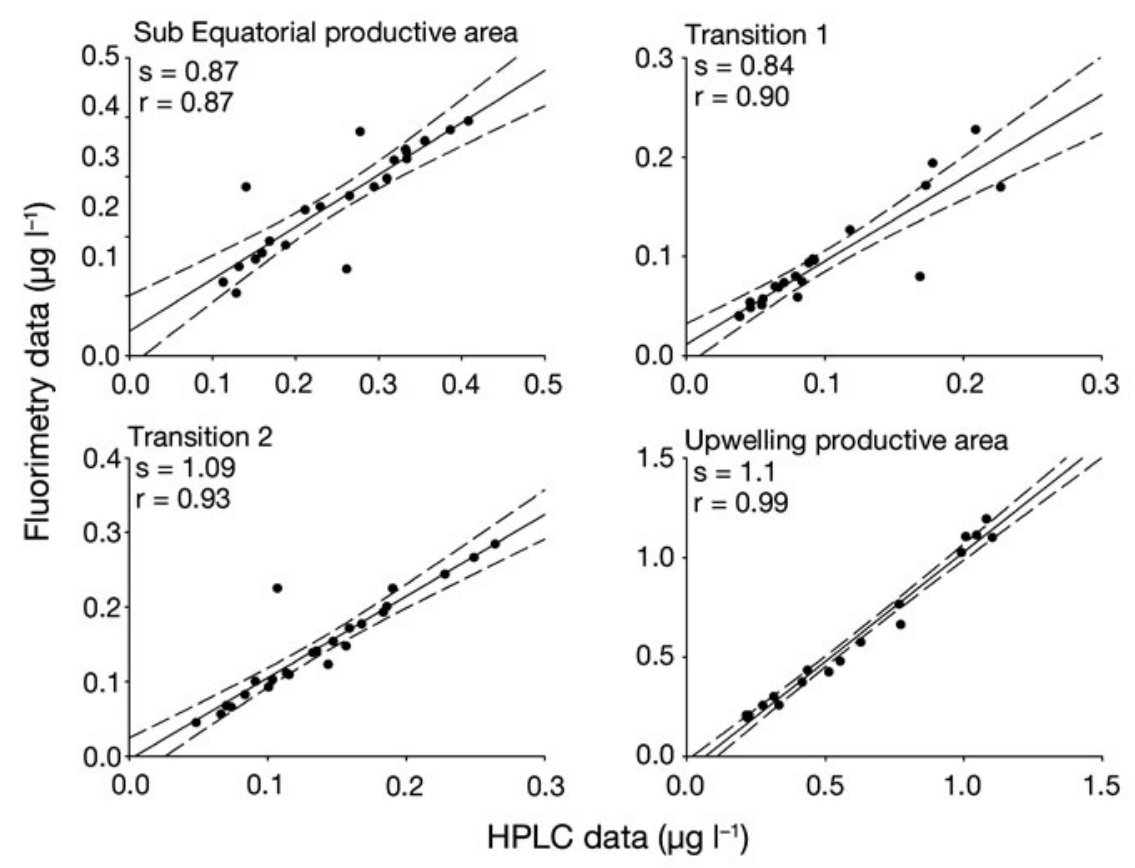

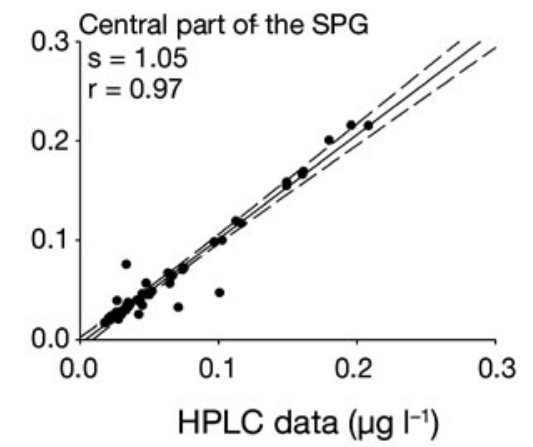

Fig. 2. Comparisons of total chl a concentrations data obtained by fluorimetry ( $y$ axis) and by HPLC ( $x$ axis) for the 5 areas of the BIOSOPE transect. Total chl a concentrations data obtained by fluorimetry corresponds to the sum of the chl a concentrations measured in the 3 size fractions $(0.2-0.6$, $0.6-2$ and $>2 \mu \mathrm{m})$. Linear regression is represented by a full line; s and $r$ correspond to the slope and the correlation coefficient, respectively; dashed lines are $95 \%$ CI 


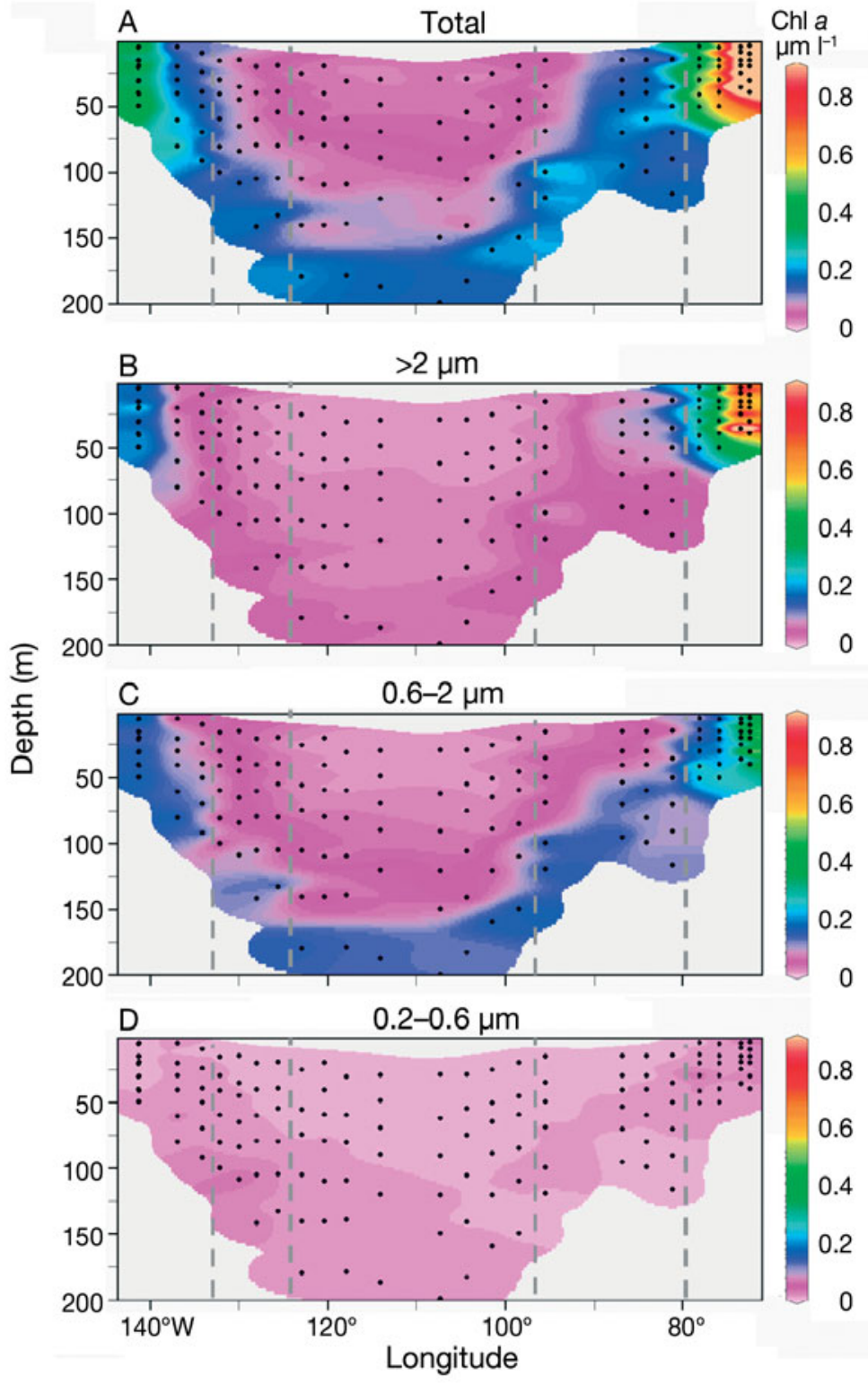

Fig. 3. Vertical distribution of chl a $\left(\mu \mathrm{g} \mathrm{l}^{-1}\right)$ in: (A) total, (B) $>2 \mu \mathrm{m}$ size fraction, (C) 0.6-2 $\mu \mathrm{m}$ size fraction and (D) 0.2-0.6 $\mu \mathrm{m}$ size fraction along the BIOSOPE transect. Vertical dashed lines indicate the boundaries between the 5 areas of the BIOSOPE transect

SPG $(60 \pm 5 \%)$. Thus, the longitudinal distribution of $\mathrm{chl}$ $a$ in the $0.6-2 \mu \mathrm{m}$ fraction closely reflected the patterns of total phytoplankton biomass. In the $>2 \mu \mathrm{m}$ fraction, chl a biomass only dominated at 3 stations over the transect: the eutrophic, UPW station (92\%) and 2 mesotrophic stations: MAR1 (59\%) and STB21 (57\%).

\section{Size-fractionated carbon incorporation rates}

C incorporation rates by autotrophic cells were higher in the SEP and UP areas (Fig. 5A-C). Through- out the area, C incorporation rates decreased with depth for the 3 size fractions. C incorporation rates in the SPG area were lower than $15 \mathrm{nmol} \mathrm{l}^{-1} \mathrm{~h}^{-1}$ for all fractions. Longitudinal variations, for euphotic layer-integrated C incorporation rates (i.e. primary production), were close to that of Ichl a (Fig. 6), with minimal values in the oligotrophic areas and maximal values in the upwelling areas. Average integrated primary production was $5494 \pm$ 1990, $3202 \pm 577,1247 \pm 544,2996 \pm 933$ and $12682 \pm 7731 \mu \mathrm{mol} \mathrm{m}{ }^{-2} \mathrm{~h}^{-1}$ in the SEP, T1, SPG, T2, and UP areas, respectively. Although the $>2 \mu \mathrm{m}$ size fraction only represented $\sim 30 \%$ of the total chl a concentration, at most of the stations, it was more important in terms of photosynthetic $\mathrm{C}$ production as it represented around half $(49 \pm 9 \%)$ of the integrated primary production (Fig. 6). The 0.2-0.6 $\mu \mathrm{m}$ fractions represented 2 to $22 \%$ (mean $=10 \pm$ $8 \%$ ) of the $\mathrm{C}$ incorporation rates, excluding Station GYRE (39\%), for which the particularly high value of $\mathrm{C}$ incorporation rates are likely due to problem of filtration (more picophytoplanktonic cells passing through the $0.6 \mu \mathrm{m}$ filter).

\section{Size-fractionated phosphate incorporation rates}

Phosphate incorporation rates were also higher in the productive areas (SEP and UP; Fig. 5D-F). In the SPG area, $\mathrm{P}$ incorporation rates were lower than $0.02 \mathrm{nmol} \mathrm{l}^{-1} \mathrm{~h}^{-1}$, whatever the fraction. $\mathrm{P}$ incorporation rates decreased with depth, with the exception of stations located in the SPG, where we measured an increase in the bottom layer of the euphotic zone (between 3 and $1 \%$ PAR). The euphotic layer-integrated $\mathrm{P}$ incorporation rates were $32 \pm 12,9 \pm 4,4 \pm 1,12 \pm 7$ and $62 \pm 41 \mu \mathrm{mol}$ $\mathrm{m}^{-2} \mathrm{~h}^{-1}$ in the SEP, T1, SPG, T2, and UP areas, respectively (Fig. 7). Heterotrophic bacteria and phytoplankton both assimilate DIP. Across the transect, the 0.2 to $0.6 \mu \mathrm{m}$ size fraction represented 15 to $43 \%$ (mean $=29 \% \pm 7 \%, \mathrm{n}=24$ ) of the integrated $\mathrm{P}$ incorporation rates. The $0.6-2 \mu \mathrm{m}$ size fraction accounted for the largest proportion of the integrated P incorporation rates in the SPG area ( $54 \pm 10 \%$, compared to $24 \pm 7 \%$ in the $>2 \mu \mathrm{m})$, while the $>2 \mu \mathrm{m}$ size fraction accounted for the largest proportion of the integrated $\mathrm{P}$ incorporation rates in the SEP area $(44 \pm 6 \%$ compared to $30 \pm$ $6 \%$ in the $0.6-2 \mu \mathrm{m}$ ) and at Station UPW (54\% compared to $15 \%$ in the $0.6-2 \mu \mathrm{m})$. 


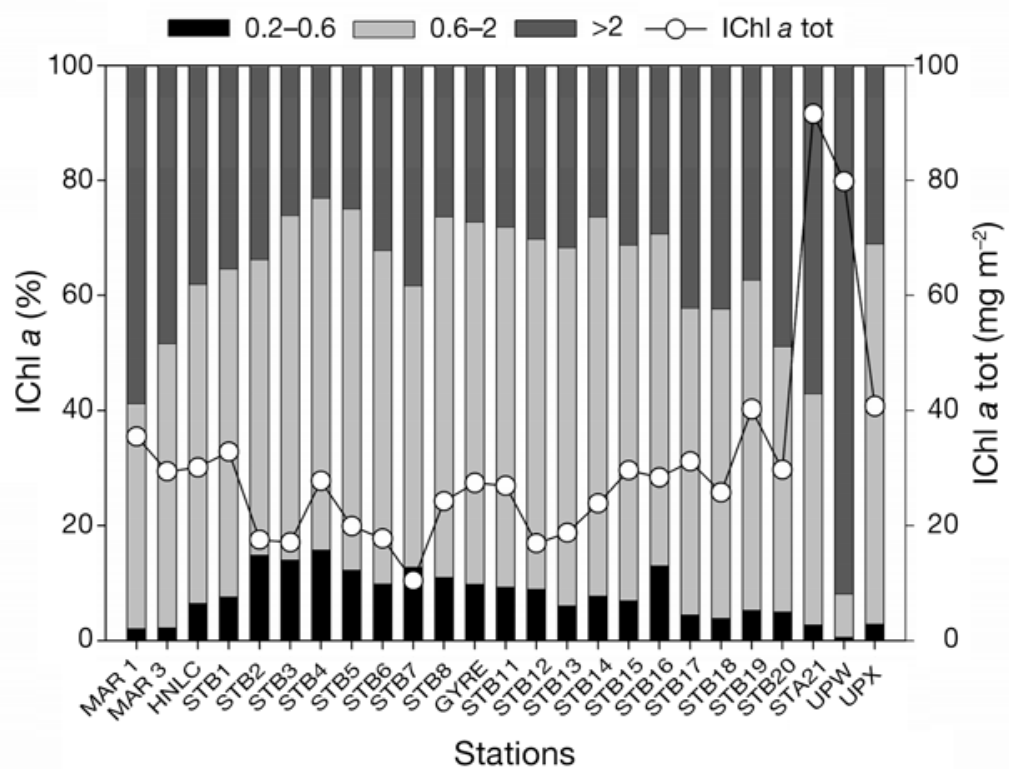

Fig. 4. Variations of the relative contribution (\%) of the $0.2-0.6,0.6-2$ and $>2 \mu \mathrm{m}$ size fractions to total euphotic-layer-integrated chl a (Ichl a) and of the total euphotic-layer-integrated chl a (Ichl a tot) along the BIOSOPE transect

\section{$\mathrm{C}: \mathrm{P}$ incorporation ratios}

For phytoplankton size fractions, integrated particulate $\mathrm{C}$ and $\mathrm{P}$ incorporation rates were compared in the 0.6-2 and $>2 \mu \mathrm{m}$ fractions taken from the euphotic layer. The C:P incorporation ratios varied between 26 and 104, and 53 and 381, respectively (Fig. 8). For the heterotrophic bacteria size fraction, the integrated ${ }^{3} \mathrm{H}$ Leu-based bacterial production data (from Van Wambeke et al. 2008) were compared to $\mathrm{P}$ incorporation rates in the $0.2-0.6 \mu \mathrm{m}$ fractions (samples from the same depths of the euphotic layer). We found that C:P incorporation ratios varied from 22 to 440 . The $\mathrm{C}: \mathrm{P}$ incorporation ratios of the $0.6-2 \mu \mathrm{m}$ fraction were lower than the Redfield (1963) ratio of 106, throughout the BIOSOPE transect $($ mean $=62 \pm 19, \mathrm{n}=24)$ although it was closer to Redfield between Stations STB13 and STB16 (mean $=96 \pm 6, \mathrm{n}=4$ ) to the east
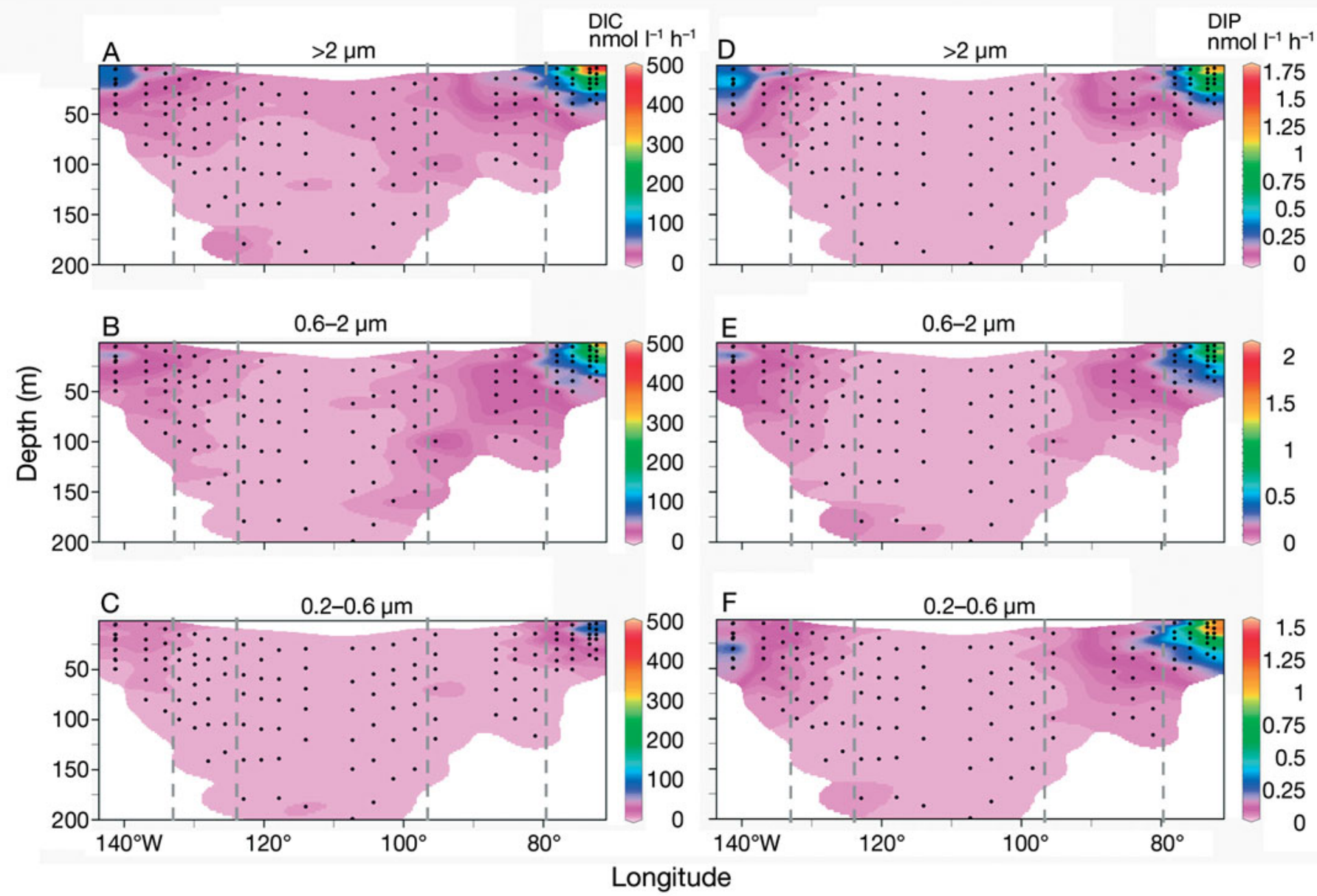

Fig. 5. Vertical distribution of (A-C) DIC and (D-F) DIP uptake rates $\left(\mathrm{nmol} \mathrm{l}^{-1} \mathrm{~h}^{-1}\right)$ in $(\mathrm{A}, \mathrm{D})$ the $>2 \mu \mathrm{m}$ size fraction, $(\mathrm{B}, \mathrm{E})$ the 0.6-2 $\mu \mathrm{m}$ size fraction and $(\mathrm{C}, \mathrm{F})$ the $0.2-0.6 \mu \mathrm{m}$ size fraction along the BIOSOPE transect. Vertical dotted lines indicate the boundaries between the 5 areas of the BIOSOPE transect 


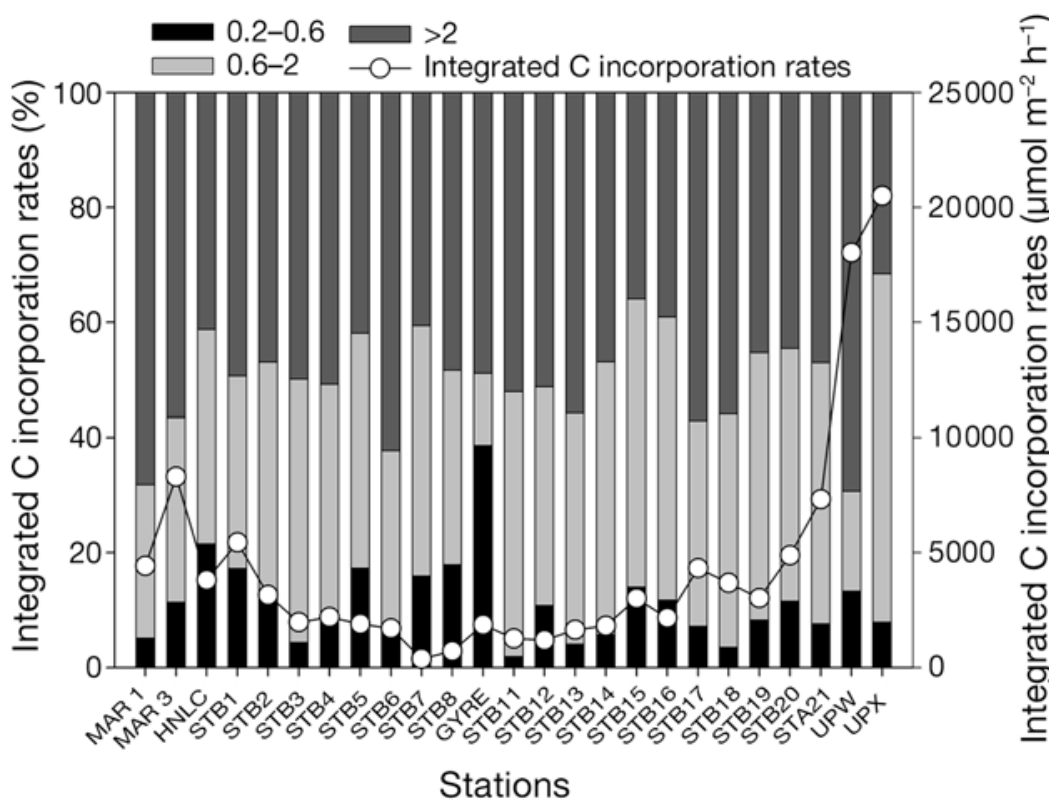

Fig. 6. Variations of the relative contribution (\%) of the $0.2-0.6,0.6-2$ and $>2 \mu \mathrm{m}$ size fractions to total euphotic-layer-integrated carbon incorporation rates (bars) and of the total euphotic-layer-integrated carbon incorporation rates (white symbols) along the BIOSOPE transect

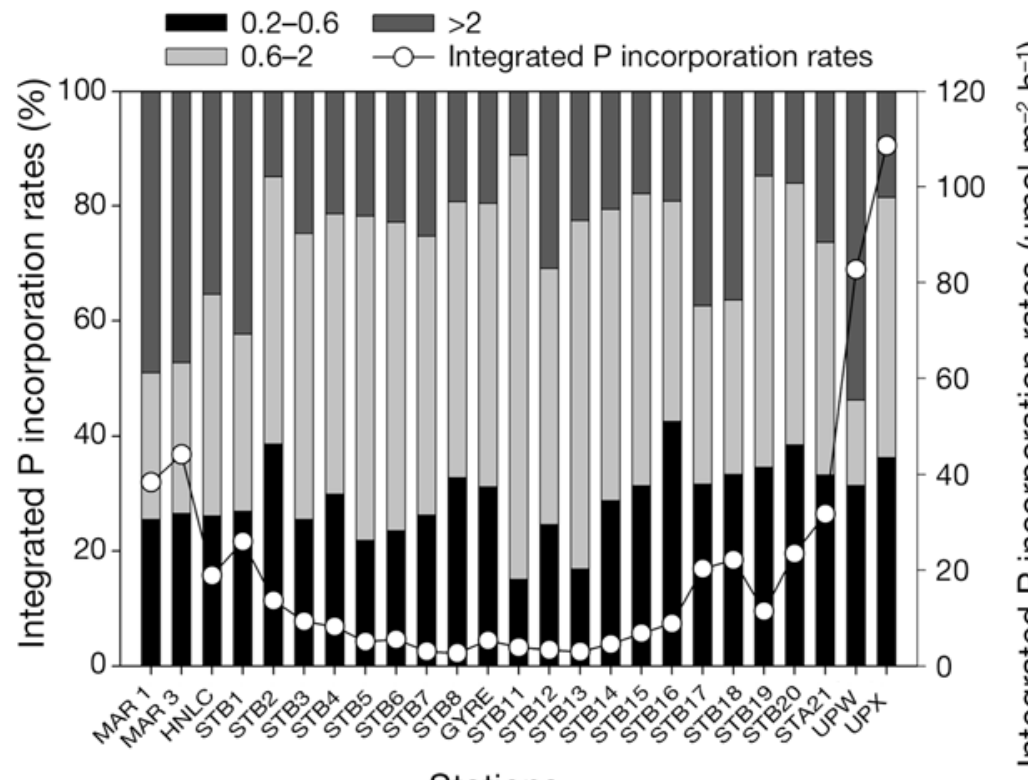

Stations

Fig. 7. Variations of the relative contribution (\%) of the $0.2-0.6 ; 0.6-2$ and $>2 \mu \mathrm{m}$ size fractions to total euphotic-layer-integrated phosphate incorporation rates (bars) and of the total euphotic-layer-integrated phosphate incorporation rates (white dots) along the BIOSOPE transect

of the SPG and west of T2. The $>2 \mu \mathrm{m}$ fraction had C:P incorporation ratios lower than 106 throughout the transect, with the exception of the SPG (mean $=231 \pm$ 95, $\mathrm{n}=7$ ), exhibiting increasing deviation from 106 from the edges to the centre of the oligotrophic gyre, reaching a maximum value of 381 at station STB11. Outside the SPG, the mean C:P incorporation ratio for the $>2 \mu \mathrm{m}$ fraction was $107 \pm 51(\mathrm{n}=17)$ and the $0.2-0.6 \mu \mathrm{m}$ size fraction followed the same trend. Outside the SPG, C:P ratios for the $0.2-0.6 \mu \mathrm{m}$ size fraction were close to the Fagerbakke et al. (1996) ratio of 50, for heterotrophic bacteria, with a mean value of $69 \pm 59(\mathrm{n}=17)$, although values were significantly higher in the SPG (mean $=249 \pm 102, n=7)$.

\section{DISCUSSION}

Flow cytometry results showed that the average size of heterotrophic bacteria and picophytoplankton cells justify the choice of $0.6 \mu \mathrm{m}$ filters to separate these 2 functional groups. Despite this, cytometry counts also showed that $34 \pm 24 \%$ of the Prochlorococcus cells and $3 \pm 5 \%$ of the Synechococcus cells were found in the $<0.6 \mu \mathrm{m}$ fraction and that $91 \pm 10 \%$ of the heterotrophic bacteria passed through the $0.6 \mu \mathrm{m}$ filter. Indeed, many factors, such as slight variability of the filters pore size, cell aggregates and filter clogging, can affect the cell separation by the filtration technique. Consequently, $\mathrm{C}$ uptake and chl a concentration results can be underestimated in the $0.6-2 \mu \mathrm{m}$ fraction and overestimated in the 0.2$0.6 \mu \mathrm{m}$ fraction due to some Prochlorococcus and Synechococcus cells passing through the $0.6 \mu \mathrm{m}$ filters. This is illustrated by the very low but significant proportion of $C$ uptake $(10 \pm 8 \%)$ and chl a concentration $(8 \pm 4 \%)$ measured in the $<0.6 \mu \mathrm{m}$ fraction. Moreover, P uptake can be biased by heterotrophic bacteria separation from phytoplankton cells. In this study, less than $10 \%$ of the heterotrophic bacteria were retained by the $0.6 \mu \mathrm{m}$ filter. It is not possible to determine the $\mathrm{P}$ uptake rate associated to these retained bacteria with our experimental design. This bias could have repercussions - mainly, C:P ratios for the $0.6-2 \mu \mathrm{m}$ fraction could be underestimated if some bacteria with high $\mathrm{P}$ incorporation rates were found in the $>0.6 \mu \mathrm{m}$ fraction. Aggregates of bacteria seem to contain highly active bacteria; Van Wambeke (pers. comm.) measured on average $36 \pm 20 \%(\mathrm{n}=37$, surface samples $)$ of the leucine-based bacterial production in the $>0.6 \mu \mathrm{m}$ fraction across the BIOSOPE transect. Assuming that 


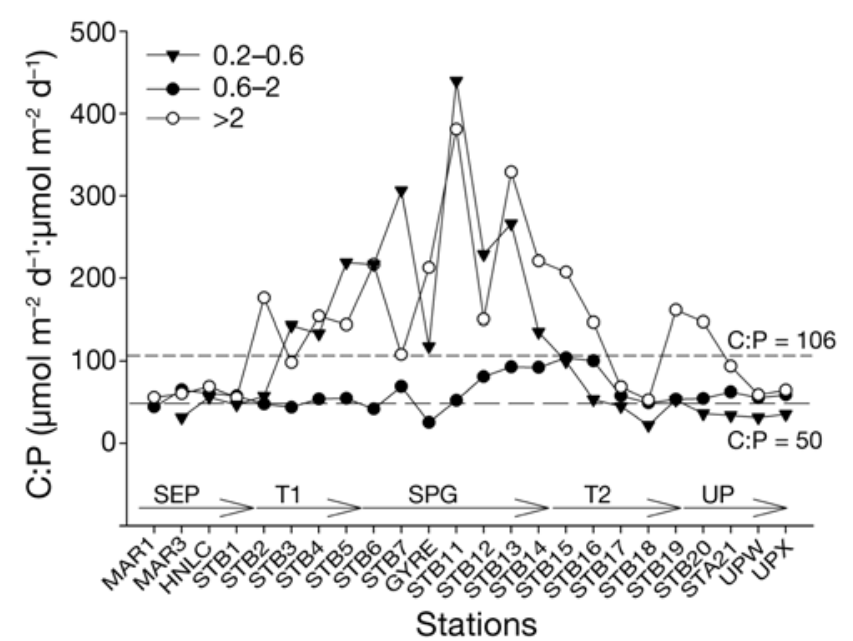

Fig. 8. Ratios (molar) of euphotic-layer-integrated carbon assimilation rates to orthophosphate uptake rates: primary production versus orthophosphate uptake in the $>2 \mu \mathrm{m}$ and $0.6-2 \mu \mathrm{m}$ size fractions and bacterial production estimated by leucine incorporation versus orthophosphate uptake in the $0.2-0.6 \mu \mathrm{m}$ size fraction. The 5 areas of the BIOSOPE transect are indicated by arrows (abbreviations as in Fig. 1). The station STB8 showed extreme values, outside the range of values obtained for the other stations all over the transect, and was removed from the analysis

the $\mathrm{P}$ incorporation rates of the bacteria held back on these filters also contributed to $36 \%$ of the bacterial $\mathrm{P}$ incorporation rates, they could give an underestimation of the C:P ratios in the $0.2-0.6 \mu \mathrm{m}$ fraction or an overestimation of the C:P ratio in the $0.6-2 \mu \mathrm{m}$ fraction. However, even if the filtration method is not free from controversy, it is still the simplest and fastest method to separate different functional groups. A promising alternative is the use of cell sorting by flow cytometry, but it is time-consuming and presents other non-negligible bias (Lipschultz 1995, Zubkov et al. 2007).

\section{Role of microorganisms in the carbon budget}

Throughout the BIOSOPE transect, the picophytoplankton (cells $<2 \mu \mathrm{m}$ ) was largely represented by Prochlorococcus spp. and picophytoeukaryotes (Grob et al. 2007). It has been demonstrated that planktonic $C$ fixation and biomass are increasingly dominated by autotrophic picophytoplankton, particularly picocyanobacteria, as systems tend towards oligotrophy (Agawin et al. 2000). In the SPG, the $<2 \mu \mathrm{m}$ fraction accounted for $69 \pm 4 \%$ of the I chl $a$ and $49 \pm 7 \%$ of integrated primary production. The picophytoplankton fraction was therefore significant in the oligotrophic SPG, as had been reported for other oligotrophic areas of the world's oceans (Agawin et al. 2000). The larger contribution of the picophytoplankton-size cells to chl a concentration than to primary production has also been previously reported in other oligotrophic areas of the open ocean (Marañón et al. 2001, Pérez et al. 2006). This difference could be the result of the increase in the cells chl a content with depth, as a result of photoacclimatation (Le Floc'h et al. 2002, Moore et al. 2006). Indeed, the subtropical gyre areas are characterized by a deep chlorophyll maximum that does not necessarily correspond to a deep phytoplankton cell concentration maximum (Pérez et al. 2006). In the SPG, most of the chl a biomass, corresponding to the $<2 \mu \mathrm{m}$ fraction, was found at the $1 \%$ PAR level. Nevertheless, in this area, picophytoplankton cell abundances (Grob et al. 2007) and P incorporation rates also increased in the bottom layer of the euphotic zone (between 3 and 1\% PAR). These results suggest that the majority of the picophytoplankton lived in the bottom layer of the euphotic zone, which was located at the vicinity of the nitracline, so enabling the smaller phytoplankton to take advantage of their large surface area to volume ratio to access $\mathrm{N}$, the limiting nutrient in the SPG (Bonnet et al. 2008). The accumulation of a picophytoplankton biomass at the level of $1 \%$ PAR is common to other oligotrophic gyres in the world's oceans (Teira et al. 2005). Though, at such depth, phytoplankton cells were characterized by low photosynthetic efficiencies (see below), which supports the idea of chl a accumulation per cell due to photoacclimatation, making the use of chl a concentration less accurate for estimating phytoplankton biomass in the deep layers of the oligotrophic areas.

In this study we demonstrated that large phytoplankton $(>2 \mu \mathrm{m}$ ) dominated the chl a biomass around the Marquesas Islands and Chilean coasts. The dominance of large phytoplankton biomasses in coastal areas has been widely documented (in the Northeast Atlantic, Donald et al. 2001; in different coastal marine environments, Morin \& Fox 2004; at a central station in the Ría de Vigo northwest of Spain, Cermeño et al. 2006). According to Donald et al. (2001), the dominance of large phytoplankton cells in nutrient replete waters must be the result of complex interactions of nutrient incorporation mechanisms, photosynthetic efficiency and the intrinsic growth rates of different phytoplankton species. However, despite representing the smallest chl a biomass, $>2 \mu \mathrm{m}$ phytoplankton yielded the same proportion of primary production as $<2 \mu \mathrm{m}$ phytoplankton in both oligotrophic and mesotrophic areas. Taylor et al. (1997) demonstrated that cells reduce their pigment content under conditions of high irradiance and restricted nutrient availability. We showed that chl a concentrations in the $>2 \mu \mathrm{m}$ fraction were uniformly distributed in the photic layer of the SPG, presenting a small peak in the DCM. Thus a large quantity of the $>2 \mu \mathrm{m}$ phytoplankton was grow- 
ing in high irradiance conditions with restricted nutrient availability, forcing them to reduce their chl a content. This result also implies that large phytoplankton had a higher photosynthetic efficiency than smallersized phytoplankton. Indeed, throughout the transect (except in the UP area), the $>2 \mu \mathrm{m}$ phytoplankton had a higher photosynthetic efficiency $(1.85 \pm 0.81 \mathrm{mg} C$ $\mathrm{mg}^{-1} \mathrm{chl} \mathrm{a} \mathrm{h}^{-1}$ ) than the $<2 \mu \mathrm{m}$ picophytoplankton $\left(0.99 \pm 0.59 \mathrm{mg} \mathrm{C} \mathrm{mg}^{-1} \mathrm{chl} \mathrm{a} \mathrm{h}^{-1}\right)$. This trend was also reported by Fernandez et al. (2003) in the subtropical and tropical regions of the Atlantic Ocean, with $3.7 \pm$ $0.3 \mathrm{mg} \mathrm{C} \mathrm{mg}^{-1} \mathrm{chl} \mathrm{a} \mathrm{h}{ }^{-1}$ for $>2 \mu \mathrm{m}$ and $1.5 \pm 0.2 \mathrm{mg} \mathrm{C}$ $\mathrm{mg}^{-1} \mathrm{chl} \mathrm{a} \mathrm{h}^{-1}$, for $0.6-2 \mu \mathrm{m}$ phytoplankton. Moreover, when calculating photosynthetic efficiencies for each depth, we found that large phytoplankton had higher photosynthetic efficiencies than the smaller phytoplankton throughout the water column and transect, underlying that larger cells need to synthesize less chl a than smaller ones to fix the same amount of $\mathrm{C}$.

\section{Role of microorganisms in the phosphate budget}

Previous studies have shown the major roles of picophytoplankton and heterotrophic bacteria in P incorporation (Bratbak \& Thingstad 1985, Lebo 1990, Thingstad et al. 1996). Because these organisms are important contributors to the plankton biomass of the tropical ocean (Gasol et al. 1997), they could have a dominant role in $\mathrm{P}$ cycling within the SEP transect. Indeed, 46 to $89 \%$ of the P was taken up by the $0.2-$ $2 \mu \mathrm{m}$ fraction. Similarly, along the $20^{\circ} \mathrm{W}$ meridian in the Northeast Atlantic between $57.5^{\circ} \mathrm{N}$ and $37^{\circ} \mathrm{N}$, Donald et al. (2001) found that P was predominantly $(>70 \%)$ incorporated into the picoplankton fraction $(0.2-2 \mu \mathrm{m})$, which included both heterotrophic and autotrophic components. The authors did not discriminate how much of the measured phosphate incorporation was due to heterotrophic bacteria or autotrophic picoplankton. In this study, we showed that the $0.2-$ $0.6 \mu \mathrm{m}$ fraction, essentially composed of heterotrophic bacteria, was responsible for almost one-third of the total $\mathrm{P}$ incorporation along the west-east transect. The importance of heterotrophic bacteria in P incorporation has received much attention since it has been demonstrated that they were not only P remineralizers (Currie \& Kalff 1984, Lebo 1990, Thingstad et al. 1996). Lebo (1990) showed that bacteria dominated P incorporation where anthropogenic inputs were high and put forward the hypothesis that the ability of bacteria to compete with phytoplankton for $\mathrm{P}$ is affected by the availability of reduced C (Currie \& Kalff 1984). Heath \& Munawar (2004) measured P incorporation in sizefractionated groups in oligotrophic freshwater ecosystems. Their results indicated that more than $61 \%$ (and up to $93 \%$ ) of the instantaneous phosphate incorporation was by bacteria in both onshore (DIP $=110 \mathrm{nmol}$ $\mathrm{l}^{-1}$ ) and offshore habitats (DIP $=75 \mathrm{nmol} \mathrm{l}^{-1}$ ). Thingstad et al. (1996) showed that the distribution of $\mathrm{P}$ between size fractions suggests a comparable role of phytoplankton and bacteria in $\mathrm{P}$ incorporation in systems where $\mathrm{P}$ turnover times are relatively long. According to Thingstad et al. (1993), extreme bacterial dominance of $\mathrm{P}$ incorporation is a characteristic of systems with short $\mathrm{P}$ turnover times (i.e. P-limited systems). This hypothesis was later confirmed in a study of 2 basins of Lake Biwa (Japan), where a P-limited system became P-sufficient due to typhoon-induced mixing (Robarts et al. 1998). The authors showed that bacteria dominated $(65 \%)$ DIP incorporation before the typhoon (i.e. Pdeficient system) while phytoplankton dominated (65\%) P incorporation rates after the typhoon (i.e. Psufficient system). Our results are also in accordance with the Thingstad et al. (1993) hypothesis.

Significant variations in the relative importance of the 2 size fractions representative of small $(0.6-2 \mu \mathrm{m})$ and large $(>2 \mu \mathrm{m})$ phytoplankton were observed. As for primary production, the $>2 \mu \mathrm{m}$ fraction accounted for the greatest phytoplankton P-based production rates in the SEP and at Station UPW $(44 \pm 6 \%$ and $54 \%$ of the integrated $\mathrm{P}$ incorporation rates, respectively). Our results are in accordance with Wang et al. (1997) who showed that nanophytoplankton $(3-20 \mu \mathrm{m})$ accounted for $75 \%$ of $\mathrm{P}$ incorporation in subtropical coastal environments. Small-sized cells $(0.6-2 \mu \mathrm{m})$ accounted for 44 to $74 \%$ of the euphotic layer-integrated $\mathrm{P}$ incorporation rates in the SPG. This suggests that where they prevailed, the small phytoplankton cells took up more DIP than the larger ones.

\section{$\mathrm{C}: \mathrm{P}$ incorporation ratios}

If the elemental composition of a cell approximates the Redfield ratio, then C:P incorporation ratios should also be close to the Redfield ratio when measured over the generation time of that cell (Thingstad et al. 1996). On time scales of less than the generation time, there may be uncoupling between photosynthesis and nutrient acquisition (Goldman et al. 1992). We showed in a previous study that the microbial community of the SPG turns over very slowly (growth rates $<0.2 \mathrm{~d}^{-1}$, Duhamel et al. 2007). So it is not surprising to find deviations from the C:P Redfield ratio over the BIOSOPE transect, particularly in the SPG, since C and P incorporation rates have been measured over short time scales ( 4 to $5 \mathrm{~h}$ ) in order to avoid the bias linked with long incubation times (see Duhamel et al. 2006). Integrating C:P incorporation rates over the euphotic zone should also reduce some uncertainties linked to noise 
(some values at the limit of the detection level, filtration bias).

The relatively high $\mathrm{C}: \mathrm{P}$ ratio values, obtained for heterotrophic bacteria $(0.2-0.6 \mu \mathrm{m}$ fraction) are not a common observation, since bacteria have been shown to have higher $\mathrm{P}$ requirements than phytoplankton (Vadstein 2000). Nevertheless, C:P ratios higher than 50 (the Fagerbakke et al. 1996 ratio for heterotrophic bacteria) have already been observed for heterotrophic bacteria in areas where DIP concentrations were not limiting relative to $N$ (Thingstad et al. 1996). Biddanda et al. (2001) showed that a C:P ratio in the $<1 \mu \mathrm{m}$ fraction was higher than, but still approached, the Redfield ratio (106) in an oligotrophic area in the eutrophic area of different lakes and in particulate matter. Indeed, studies presenting C:P incorporation rates are scarce and most works providing $\mathrm{C}: \mathrm{P}$ ratio values in different size fractions deal with particulate matter. Slowly growing cells are characterized by high C:P ratios compared to rapidly growing cells (Chrzanowski et al. 1996). Duhamel et al. (2007) showed that in the euphotic zone of the oligotrophic area associated to the SPG, heterotrophic bacteria were growing slowly $\left(0.09 \pm 0.10 \mathrm{~d}^{-1}\right)$. Nevertheless, the use of a conversion factor to convert leucine incorporation rates to $\mathrm{C}$ incorporation rates could be a source of error on bacterial production and thus on the heterotrophic bacteria C:P ratio estimates. Indeed, the conversion factors are not systematically determined and only some empirical conversion factors have been determined for the leucine method in marine pelagic systems. Consequently, the choice of one of these conversion factors to determine bacterial production is still a subject of debate (Duhamel et al. 2007, Van Wambeke et al. 2008).

Bonnet et al. (2008) showed that the phytoplanktonic community at the hyperoligotrophic GYRE station presented the highest quantum yield, suggesting a particular adaptation to the extremely poor conditions encountered at the centre of the gyre. Moreover, P-based values of specific growth rates determined in the SPG by Duhamel et al. (2007) showed that small phytoplankton was growing faster than the large fraction $\left(0.14 \pm 0.04\right.$ and $0.05 \pm 0.02 \mathrm{~d}^{-1}$, respectively, Duhamel et al. 2007). Thus, small phytoplankton seemed to be better adapted to the particular oligotrophic environment far from terrestrial influences than large phytoplankton. With the exception of the T2 area, the C:P incorporation ratios of the $0.6-2 \mu \mathrm{m}$ fraction were almost half the Redfield ratio value (106), particularly in the SPG, suggesting that the picophytoplanktonsize cells had higher $\mathrm{P}$ requirements than the larger cells. The low C:P ratios obtained for the $0.6-2 \mu \mathrm{m}$ fraction are thus in accordance with the increase of $\mathrm{P}$ incorporation rates in the bottom layer of the euphotic zone (between 3 and 1\% PAR) where maximal chl a concentrations and picophytoplankton cell abundances were measured. Urabe \& Sterner (1996) and Elser et al. (2003) also showed that C:P ratios (C to P contents) tend to be low under low light conditions and abundant P. Similarly, Hessen et al. (2002) showed that adaptation of algal cells to low light conditions not only involves a cost in terms of increased chl a synthesis, but also in terms of increased $\mathrm{P}$ demands.

Because $\mathrm{P}$ was not a limiting element throughout the BIOSOPE transect, the high molar C:P ratios (>106) measured for the large phytoplankton were not due to $\mathrm{P}$ limitation and can be explained by high relative $\mathrm{C}$ incorporation rates. Indeed, while the large cell fraction accounted for $22 \pm 6 \%$ of integrated P incorporation rates, they represented $51 \pm 7 \%$ of the integrated $\mathrm{C}$ incorporation rates. In the SPG, organisms were $\mathrm{N}$ limited (Bonnet et al. 2008) and were growing in high light conditions (depth of the $1 \%$ of PAR was 136 to $167 \mathrm{~m}$ in the SPG) due to the clearness of the waters (Morel et al. 2007). Thus, high relative $\mathrm{C}$ incorporation rates could be the result of large phytoplankton adaptation to the SPG environment. As an example, under conditions of saturating light and $\mathrm{N}$ limitation, certain phytoplankton cells can store $\mathrm{C}$ as lipids or carbohydrates, which increases their C:P ratio (Hessen et al. 2002). According to the hypothesis of Wood \& Van Valen (1990), such conditions can also lead the cells to release photosynthate. The release of photosynthate can serve 2 beneficial functions: (1) when nutrients do become available, nutrient-limited cells maximize their growth rates, by eliminating the lag period for resumption of $\mathrm{C}$ fixation and growth; and (2) biochemical reductant can be accommodated physiologically even if storage pools are saturated, providing protection of the photosynthetic apparatus. The latter benefit would be of particular interest in the gyre area, where deep penetration of visible and UV radiations were measured $\left(\mathrm{Z}_{10 \%}[\mathrm{UVB}]=21 \mathrm{~m}\right.$ at GYRE station, Tedetti et al. 2007).

The C:P ratios obtained for the $0.2-0.6$ and the $>2 \mu \mathrm{m}$ fractions showed a surprising covariation along the transect $\left(\mathrm{r}^{2}=0.6, \mathrm{p}<0.05, \mathrm{n}=23\right)$, while no relation was found for the $0.6-2 \mu \mathrm{m}$ fraction. Since heterotrophic bacteria and phytoplankton cells acquire $\mathrm{C}$ from different sources, the $\mathrm{C}: \mathrm{P}$ ratios have been calculated differently for the $0.2-0.6$ and the $>2 \mu \mathrm{m}$ fractions (see 'Materials and methods') and consequently, the covariation between C:P ratios in these fractions is not likely to be due to our methodological setting. Such a covariation could be explained by the coupling between heterotrophic bacteria and large phytoplankton $\mathrm{C}$ production. As mentioned previously, the high molar C:P ratios (>106) measured for the large phytoplankton can be explained by high relative $\mathrm{C}$ incorporation 
rates, which are likely to go with high dissolved organic C (DOC) excretion. This DOC excretion could provide a labile $\mathrm{C}$ source for bacterial production. Indeed, the results of Van Wambeke et al. (2008) suggest potentially high percentages of DOC production rates and a strong coupling between primary production and heterotrophic bacterial production in the SPG.

In conclusion, determining $\mathrm{C}$ and $\mathrm{P}$ incorporation rates in 3 different size fractions allowed us to obtain a better picture of the relative activity of these groups of planktonic organisms. Indeed, by studying C:P incorporation rates and considering the Redfield value as a reference, it is possible to better understand the organisms' relative needs in relation with their environment. Heterotrophic bacteria were important contributors of $\mathrm{P}$ cycling, as they represented 15 to $43 \%$ (mean $=29 \pm$ $7 \%, \mathrm{n}=24$ ) of the total planktonic community P incorporation rates over the BIOSOPE transect. Even presenting a non negligible fraction of the $\mathrm{P}$ incorporation rates, this fraction presented particularly high C:P incorporation rates, suggesting relatively high $\mathrm{C}$ production by heterotrophic bacteria. This high production can be sustained by high DOC excretion by large phytoplankton - which presented very high $\mathrm{C}$ incorporation in the SPG ( $>40 \%$ of the total phytoplankton $\mathrm{C}$ incorporation rate). On the other hand, the $0.6-2 \mu \mathrm{m}$ fraction dominated both chl a concentration and $\mathrm{P}$ incorporation rates in the SPG but had low C:P incorporation ratios, in accordance with low light adaptation.

Acknowledgements. We express our gratitude to O. Ulloa, G. Alarcon and C. Grob for providing us cytometry data. We thank T. Bentley for help with improving the English. We also thank the crew of the RV 'L'Atalante' for outstanding shipboard support operations. D. Tailliez and C. Bournot are warmly thanked for their efficient help in CTD rosette management and data processing. This is a contribution to the BIOSOPE project of the LEFE-CYBER program. This research was funded by the Centre National de la Recherche Scientifique (CNRS), the Institut des Sciences de l'Univers (INSU), the Centre National d'Etudes Spatiales (CNES), the European Space Agency (ESA), The National Aeronautics and Space Administration (NASA) and the Natural Sciences and Engineering Research Council of Canada (NSERC). This work is funded in part by the French Research and Education council.

\section{LITERATURE CITED}

Agawin NSR, Duarte CM, Agusti S (2000) Nutrient and temperature control of the contribution of picoplankton to phytoplankton biomass and production. Limnol Oceanogr 45:591-600

Biddanda B, Ogdahl M, Cotner J (2001) Dominance of bacterial metabolism in oligotrophic relative to eutrophic waters. Limnol Oceanogr 46:730-739

Bonnet S, Guieu C, Bruyant F, Prá?il O and others (2008) Nutrient limitation of primary productivity in the Southeast Pacific (BIOSOPE cruise). Biogeosciences 5:215-225
Bratbak G, Thingstad TF (1985) Phytoplankton-bacteria interactions: an apparent paradox? Analysis of a model system with both competition and cornmensalism. Mar Ecol Prog Ser 25:23-30

Cermeño P, Marañón E, Pérez V, Serret P, Fernandez E, Castro CG (2006) Phytoplankton size structure and primary production in a highly dynamic coastal ecosystem (Ria de Vigo, NW-Spain): Seasonal and short-time scale variability. Estuar Coast Shelf Sci 67:251-266

Chrzanowski TH, Kyle M, Elser JJ, Sterner RW (1996) Element ratios and growth dynamics of bacteria in an oligotrophic Canadian shield lake. Aquat Microb Ecol 11:119-125

> Claustre H, Maritorena S (2003) The many shades of ocean blue. Science 302:1514-1515

Currie DJ, Kalff J (1984) The relative importance of bacterioplankton and phytoplankton in phosphorus uptake in freshwater. Limnol Oceanogr 29:311-321

Donald KM, Joint I, Rees AP, Malcolm S, Woodward E, Savidge G (2001) Uptake of carbon, nitrogen and phosphorus by phytoplankton along the $20^{\circ} \mathrm{W}$ meridian in the NE Atlantic between $57.5^{\circ} \mathrm{N}$ and $37^{\circ} \mathrm{N}$. Deep-Sea Res II 48:873-897

Duhamel S, Zeman F, Moutin T (2006) A dual-labeling method for the simultaneous measurement of dissolved inorganic carbon and phosphate uptake by marine planktonic species. Limnol Oceanogr Methods 4:416-425

Duhamel S, Moutin T, Van Wambeke F, Van Mooy B, Rimmelin P, Raimbault P, Claustre H (2007) Growth and specific P-uptake rates of bacterial and phytoplanktonic communities in the Southeast Pacific (BIOSOPE cruise). Biogeosciences 4:941-956

Elser JJ, Kyle M, Makino W, Yoshida T, Urabe J (2003) Ecological stoichiometry in the microbial food web: a test of the light:nutrient hypothesis. Aquat Microb Ecol 31:49-65

Fagerbakke KM, Heldal M, Norland S (1996) Content of carbon, nitrogen, oxygen, sulfur and phosphorus in native aquatic and cultured bacteria. Aquat Microb Ecol 10: 15-27

Falkowski PG, Davis CS (2004) Natural proportions. Nature 431:131

Fernandez E, Marañón E, Morán X, Serret P (2003) Potential causes for the unequal contribution of picophytoplankton to total biomass and productivity in oligotrophic waters. Mar Ecol Prog Ser 254:101-109

Gasol JM, Del Giogio P, Duarte CM (1997) Biomass distribution in marine planktonic communities. Limnol Oceanogr 42:1353-1363

Goldman JC, Hansell DA, Dennett MR (1992) Chemical characterization of three large oceanic diatoms: potential impact on water column chemistry. Mar Ecol Prog Ser 88:257-270

Grob C, Ulloa O, Claustre H, Huot Y, Alarcón G, Marie D (2007) Contribution of picoplankton to the total particulate organic carbon concentration in the eastern South Pacific. Biogeosciences 4:837-852

> Heath RT, Munawar M (2004) Bacterial productivity in Lake Superior, 2001: Implications for food web efficiencies in oligotrophic freshwater ecosystems. Aquat Ecosyst Health Manage 7:465-473

Hessen DO, Faerovig PJ, Andersen T (2002) Light, nutrients, and $P$ : $C$ ratios in algae: Grazer performance related to food quality and quantity. Ecology 83:1886-1898

Le Floc'h E, Malara, G, Sciandra, A (2002) An automatic device for in vivo absorption spectra acquisition and chlorophyll estimation in phytoplankton cultures. J Appl Phycol V14:435-444 
Lebo ME (1990) Phosphate uptake along a coastal plain estuary. Limnol Oceanogr 35:1279-1289

Legendre L, Rassoulzadegan F (1996) Food-web mediated export of inorganic carbon in ocean: hydrodynamic control. Mar Ecol Prog Ser 145:179-193

Lipschultz F (1995) Nitrogen-specific uptake rates of marine phytoplankton isolated from natural populations of particles by flow cytometry. Mar Ecol Prog Ser 123:245-258

Longhurst A, Sathyendranath S, Platt T, Caverhill C (1995) An estimate of global primary production in the ocean from satellite radiometer data. J Plankton Res 17: 1245-1271

Marañón E, Holligan P, Barciela R, González N, Mouriño B, Pazo M, Varela M (2001) Patterns of phytoplankton size structure and productivity in contrasting open-ocean environments. Mar Ecol Prog Ser 216:43-56

Moore CM, Ostrowski M, Scanlan DJ, Feren K, Sweetsir T (2006) Phytoplankton photoacclimation and photoadaptation in response to environmental gradients in a shelf sea. Limnol Oceanogr 51:936-949

Morel A, Gentili B, Claustre H, Babin M, Bricaud A, Ras J, Tieche F (2007) Optical properties of the 'clearest' natural waters. Limnol Oceanogr 52:217-229

Morin PJ, Fox JW (2004) Ecology: Diversity in the deep blue sea. Nature 429:813-814

Moutin T, Raimbault P, Poggiale JC (1999) Production primaire dans les eaux de surface de la Méditerranée occidentale. Calcul de la production journalière. C R Académie des Sciences 322:651-659

Moutin T, Karl DM, Duhamel S, Rimmelin P, Raimbault P, Van Mooy BAS, Claustre H (2008) Phosphate availability and the ultimate control of new nitrogen input by nitrogen fixation in the tropical Pacific Ocean. Biogeosciences 5: 95-109

Obernosterer I, Kawasaki N, Benner R (2003) P-limitation of respiration in the Sargasso Sea and uncoupling of bacteria from P-regeneration in size-fractionation experiments. Aquat Microb Ecol 32:229-237

Pérez V, Fernandez E, Marañón E, Morán XAG, Zubkov MV (2006) Vertical distribution of phytoplankton biomass, production and growth in the Atlantic subtropical gyres. Deep-Sea Res I 53:1616-1634

Raimbault P, Garcia N, Cerutti F (2008) Distribution of inorganic and organic nutrients in the South Pacific Oceanevidence for long-term accumulation of organic matter in nitrogen-depleted waters. Biogeosciences 5:281-298

Ras J, Claustre H, Uitz J (2008) Spatial variability of phytoplankton pigment distributions in the Subtropical South Pacific Ocean: comparison between in situ and predicted data. Biogeosciences 5:353-369

Redfield AC (1934) On the proportions of organic derivations in seawater and their relation to the composition of plankton. In: Daniel RJ (ed) James Johnson Memorial Volume. University Press of Liverpool, p 177-192

Editorial responsibility: Hans Heinrich Janssen, Oldendorf/Luhe, Germany
Redfield AC, Ketchum BH, Richards FA (1963) The influence of organisms on the composition of seawater. In: Hill MN (ed) The sea, Wiley, New York, p 26-77

Robarts RD, Waker MJ, Hadas O, Zohary T, Maclntyre S (1998) Relaxation of phosphorus limitation due to typhooninduced mixing in two morphologically distinct basins of Lake Biwa, Japan. Limnol Oceanogr 43:1023-1036

Taylor A, Geider R, Gilbert F (1997) Seasonal and latitudinal dependencies of phytoplankton carbon-to-chlorophyll a ratios: results of a modelling study. Mar Ecol Prog Ser 152:51-66

Tedetti M, Sempéré R, Vasilkov A, Charrière B, Nérini D, Miller WL, Kawamura K, Raimbault P (2007) High penetration of hyperviolet radiation in the south east Pacific waters. Geophysical Res Lett 34:L12610, doi:12610.11029/ 12007GL029823

Teira E, Mouriño B, Marañón E, Pérez V, Pazo MJ, Serret $P$, de Armas D, Escanez J, Woodward EMS, Fernandez E (2005) Varibility of chlorophyll and primary production in the Eastern North Atlantic Subtropical Gyre: potential factors affecting phytoplankton activity. Deep-Sea Res I 52: $569-588$

Thingstad TF, Skjoldal EF, Bohne RA (1993) Phosphorus cycling and algal-bacterial competition in Sandsfjord, western Norway. Mar Ecol Prog Ser 99:239-259

Thingstad TF, Riemann B, Havskum H, Garde K (1996) Incorporation rates and biomass content of $\mathrm{C}$ and $\mathrm{P}$ in phytoplankton and bacteria in the Bay of Aarhus (Denmark) June 1992. J Plankton Res 18:97-121

> Urabe J, Sterner RW (1996) Regulation of herbivore growth by the balance of light and nutrients. Proc Natl Acad Sci USA 93:8465-8469

Vadstein O (2000) Heterotrophic, planktonic bacteria and cycling of phosphorus: Phosphorus requirements, competitive ability, and food web interactions. Adv Microb Ecol 16:115-168

Van Wambeke F, Bonnet S, Moutin T, Raimbault P, Alarçon G, Guieu C (2007) Factors limiting heterotrophic bacterial production in the southern Pacific Ocean. Biogeosciences Discuss 4:3799-3828

Van Wambeke F, Obernosterer I, Moutin T, Duhamel S, Ulloa O, Claustre H (2008) Heterotrophic bacterial production in the eastern South Pacific: longitudinal trends and coupling with primary production. Biogeosciences 5:157-169

Wang H, Huang B, Hong H (1997) Size-fractionated productivity and nutrient dynamics of phytoplankton in subtropical coastal environments. Hydrobiologia 352:97-106

Wood A, Van Valen L (1990) Paradox lost? On the release of energy-rich compounds by phytoplankton. Mar Microb Food Webs 4:103-116

Zubkov MV, Mary I, Malcolm E, Woodward S, Warwick PE, Fuchs BM, Scanlan DJ, Burkill PH (2007) Microbial control of phosphate in the nutrient-depleted North Atlantic subtropical gyre. Environ Microbiol 9:2079-2089. doi:2010. 1111/j.1462-2920.2007.01324.x

Submitted: May 7, 2008; Accepted: October 1, 2008 Proofs received from author(s): December 19, 2008 